\title{
Survey of Plant-Parasitic Nematodes Associated with Cotton in Nuh and Palwal Districts of Haryana
}

\author{
Vinod Kumar ${ }^{1 *}$, Prakash Banakar $^{2}$, Anil Kumar $^{3}$ and Priyanka Duggal ${ }^{4}$
}

Dept. of Nematology, Chaudhary Charan Singh Haryana Agricultural University, Hisar, Haryana (125 004), India

\section{Corresponding Author}

Vinod Kumar

e-mail: vinodnagal09@gmail.com

\author{
Article History \\ Article ID: IJEP0360 \\ Received in $12^{\text {th }}$ January, 2020 \\ Received in revised form $26^{\text {th }}$ January, 2020 \\ Accepted in final form $03^{\text {rd }}$ February, 2020
}

\begin{abstract}
An extensive survey was conducted to assess the frequency and abundance of plant-parasitic nematodes associated with cotton (Gossypium hirsutum L.) in Haryana (Nuh and Palwal districts) during 2018-20. Based on incidence, population density and associated damage on affected crops, root-knot nematode (Meloidogyne incognita) was considered to be the most important parasite of the crops under local condition. During 2018-19, a total of 11 soil and root samples of cotton were collected from Nuh and Palwal districts. Out of these, eight were found infected with $M$. incognita with $72.0 \%$ frequency of occurrence. The results revealed that out of 7 samples (Nuh), five were found infested with $M$. incognita with $71.4 \%$ frequency of occurrence. In Palwal district, this nematode had $75.0 \%$ frequency of occurrence with density range of $60-300 \mathrm{j}_{2} 200^{-1} \mathrm{cc}$ soil. During 2019-20, a total of 27 soil and root samples of cotton were collected from Nuh and Palwal districts. Out of these, 14 were found infected with $M$. incognita with $51.8 \%$ frequency of occurrence. The results revealed that out of 21 samples (Nuh), 12 were found infested with $M$. incognita with $57.1 \%$ frequency of occurrence and density range of $95-690 \mathrm{j}_{2} 200^{-1}$ cc soil. In Palwal district, this nematode had 33.3\% frequency of occurrence ( 2 out of 6 samples) with density range of $135-435 \mathrm{j}_{2} 200^{-1} \mathrm{cc}$ soil. Other plant parasitic nematodes which were found associated with the cotton belonged to Rotylenchulus reniformis, Hoplolaimus sp., Helicotylenchus sp. and Tylenchorhynchus sp.
\end{abstract}

Keywords: Meloidogyne incognita, plant-parasitic nematodes, survey

\section{Introduction}

Cotton (Gossypium hirsutum L.), popularly known as 'White Gold', is an important cash crop of India. The production and productivity in India is of great concern owing to the demand for cotton all over the world. India produces around 377 lakh bales of cotton from an area of 1225.35 lakh ha with productivity of $524 \mathrm{~kg} \mathrm{ha}^{-1}$. However, the production potential of the crop has not been fully exploited due to numerous biotic and abiotic factors. One of the prime challenges to attain high cotton production is damage caused by plant-parasitic nematodes. Globally, the most damaging nematodes of cotton are Meloidogyne incognita races 3 and 4 and Rotylenchulus reniformis. $M$. incognita and $R$. reniformis occur in tropical, subtropical and warm temperate soils throughout most of the world, generally within $35^{\circ}$ of the equator (Robinson et al., 2001; Taylor and Sasser, 1978). One or both species are present in most cotton-producing regions and are considered to be serious problems in cotton production wherever they occur. The root-knot nematode, $M$. incognita, is widespread and a major pathogen in cotton production areas worldwide (Starr et al., 2005), causing direct damage and increasing the incidence and severity of the root diseases. In the United States, $M$. incognita is found on cotton in all cotton-producing states and $R$. reniformis occurs only in states east of New Mexico (Heald and Robinson, 1990; Koenning et al., 2004; Lawrence and McLean, 1996; Robinson, 2007).

Besides inflicting direct losses in crop yields, plant-parasitic nematodes also play an important role in disease complexes involving other pathogens. The expression of damage in crop plants due to plant parasitic nematodes often goes unnoticed for want of diagnostic symptoms. Based on this comprehensive survey on a global scale, the annual economic crop yield losses due to plant parasitic nematodes in major crops have been estimated to be USD 173 billion (Elling, 2013). As such, the annual cotton yield loss due to damage by plant parasitic nematodes on a worldwide basis is estimated to be $10.7 \%$ (Sasser and Freckman, 1987). In Georgia in 2012, M. incognita caused an estimated $10.0 \%$ reduction in yield resulting in a loss of 75,000,000 kg of lint (Blasingame and Patel, 2013). In India, the annual cotton yield loss due to damage by root-knot nematodes is estimated to be $20.5 \%$ (Kumar at el., 2020). Not much information is available on the distribution of 
plant parasitic nematodes around the rhizosphere of cotton in Nuh and Palwal districts of Haryana. Hence, in the present study an attempt has been made to assess the frequency and abundance of plant-parasitic nematodes associated with cotton in Haryana (Nuh and Palwal districts).

\section{Materials and Methods}

Surveys were conducted in the major cotton growing villages of districts of Nuh and Palwal districts of Haryana during 2018-20. The samples were collected from individual fields from villages within tehsils (administrative subunit of a district) of each of the two districts. Soil and root samples of plants exhibiting nematode symptoms were collected and analyzed for plant parasitic nematodes. Composite samples of soil and root were collected randomly from rhizosphere of disease infected cotton crops. When the samples were being collected, the farmers and villagers were interviewed to collect data on previous crop history, cropping pattern, fertilizer, irrigation and pesticide inputs. Soil samples were collected in polythene bags, labeled, handled and refrigerated at 7-10 ${ }^{\circ} \mathrm{C}$ before processing. Data on nematode population densities were analyzed to assess the average density of each nematode species, and frequency of occurrence in each district.

\subsection{Extraction of nematodes from soil samples}

Cobb's decanting and sieving combined with Modified Baermann's funnel technique (Schindler, 1961) was used for the extraction of nematodes from soil samples collected during survey. Killing and fixing of nematodes was done by adding boiling fixative ( $8 \%$ formalin) to nematode suspension. The nematode suspension further processed by glycerol ethanol method for identification of nematodes. Nematode population as estimated by using a stereoscope microscope and the range was determined. The species of root-knot nematode was identified by its perennial pattern.

\section{Results and Discussion}

Survey of Nuh and Palwal districts was conducted for the presence of plant-parasitic nematodes during 2018-20. Soil samples were collected from different locations along with roots. The samples were analyzed as per the standard protocol. During 2018-19, a total of 11 soil and root samples of cotton were collected from Nuh and Palwal districts. Out 11 of samples, eight were found infected with root-knot nematode with $72.0 \%$ frequency of occurrence (Table 1). Other plant parasitic nematodes which were found associated with cotton belonged to Hoplolaimus sp. (63.6\%), Helicotylenchus sp. (9.0\%), Tylenchorhynchus sp. (9.0\%) and R. reniformis (90.9\%). A total of seven soil and root samples were collected from Nuh district (Table 2). Similarly, four samples were collected from Palwal district. The results revealed that out of seven samples (Nuh), five were found infested with root-knot nematode with $71.4 \%$ frequency of occurrence. In Palwal district, this nematode had $75.0 \%$ frequency of occurrence with density range of $60-300 \mathrm{j}_{2} 200^{-1} \mathrm{cc}$ soil (Table 3 ).

\begin{tabular}{llc}
\hline \multicolumn{2}{l}{$\begin{array}{l}\text { Table 1: Nematode associated with cotton in Nuh and Palwal } \\
\text { districts of Haryana (2018-20) }\end{array}$} \\
\hline Year & Nematode & $\begin{array}{c}\text { Frequency of } \\
\text { occurrence (\%) }\end{array}$ \\
\hline 2018-19 & Meloidogyne incognita & 72.0 \\
& Hoplolaimus sp. & 63.6 \\
& Helicotylenchus sp. & 9.0 \\
& Tylenchorhynchus sp. & 9.0 \\
& Rotylenchulusreniformis & 90.9 \\
2019-20loidogyne incognita & 51.8 \\
& Hoplolaimus sp. & 40.7 \\
& Helicotylenchus sp. & 25.9 \\
& Rotylenchulusreniformis & 40.7 \\
& Pratylenchus sp. & 62.9 \\
\hline
\end{tabular}

Table 2: Distribution of root-knot nematode ( $M$. incognita) in Haryana associated with cotton crop (2018-19)

\begin{tabular}{|c|c|c|c|c|c|c|}
\hline \multirow[t]{2}{*}{$\begin{array}{l}\text { Sr. } \\
\text { No. }\end{array}$} & \multicolumn{2}{|c|}{$\begin{array}{l}\text { GPS Informa- } \\
\text { tion }\end{array}$} & \multicolumn{3}{|c|}{$\begin{array}{c}\text { Sample } \\
\text { Information }\end{array}$} & \multirow{2}{*}{$\begin{array}{l}\text { Root-knot } \\
\text { nematode } \\
200^{-1} \mathrm{cc} \\
\text { soil }\end{array}$} \\
\hline & Lat. & Long. & Village & Block & $\begin{array}{l}\text { Dis- } \\
\text { trict }\end{array}$ & \\
\hline 1 & 28.181 & 76.958 & Charodu & Taoru & Nuh & 1080 \\
\hline 2 & 28.163 & 76.959 & Charodu & Taoru & & 300 \\
\hline 3 & 28.126 & 76.982 & Biwan & Taoru & & 0 \\
\hline 4 & 28.073 & 77.054 & Adbar & Taoru & & 180 \\
\hline 5 & 28.076 & 77.054 & Adbar & Taoru & & 0 \\
\hline 6 & 28.076 & 77.054 & Adbar & Taoru & & 180 \\
\hline 7 & 28.099 & 77.018 & Salaheri & Taoru & & 180 \\
\hline 8 & 28.114 & 77.059 & Sohabha & Hodal & Pal- & 0 \\
\hline 9 & 28.129 & 77.231 & Badha & Hodal & wal & 300 \\
\hline 10 & 28.185 & 77.254 & Dhatir & Hodal & & 60 \\
\hline 11 & 28.139 & 77.302 & Hodal & Hodal & & 180 \\
\hline
\end{tabular}

During 2019-20, a total of 27 samples of cotton were collected from Nuh and Palwal districts. Out of 27 samples, 14 were found infected with, Meloidogyne incognita with $51.8 \%$ frequency of occurrence (Table 1). Other plant parasitic nematodes which were found associated with the cotton were Hoplolaimus sp., Helicotylenchus sp., Pratylenchussp. and $R$. reniformis with frequency of occurrence as 40.7, 25.9, 62.9 and $40.7 \%$, respectively. A total of 21 samples were collected from Nuh district (Table 4). Similarly, six samples were collected from Palwal district. The results revealed that out of 21 samples (Nuh), 12 were found infested with rootknot nematode with 57.1\% frequency of occurrence. In Palwal district, this nematode had $33.3 \%$ frequency of occurrence with density range of $135-435 \mathrm{j}_{2} 200^{-1} \mathrm{cc}$ soil (Table 5). 


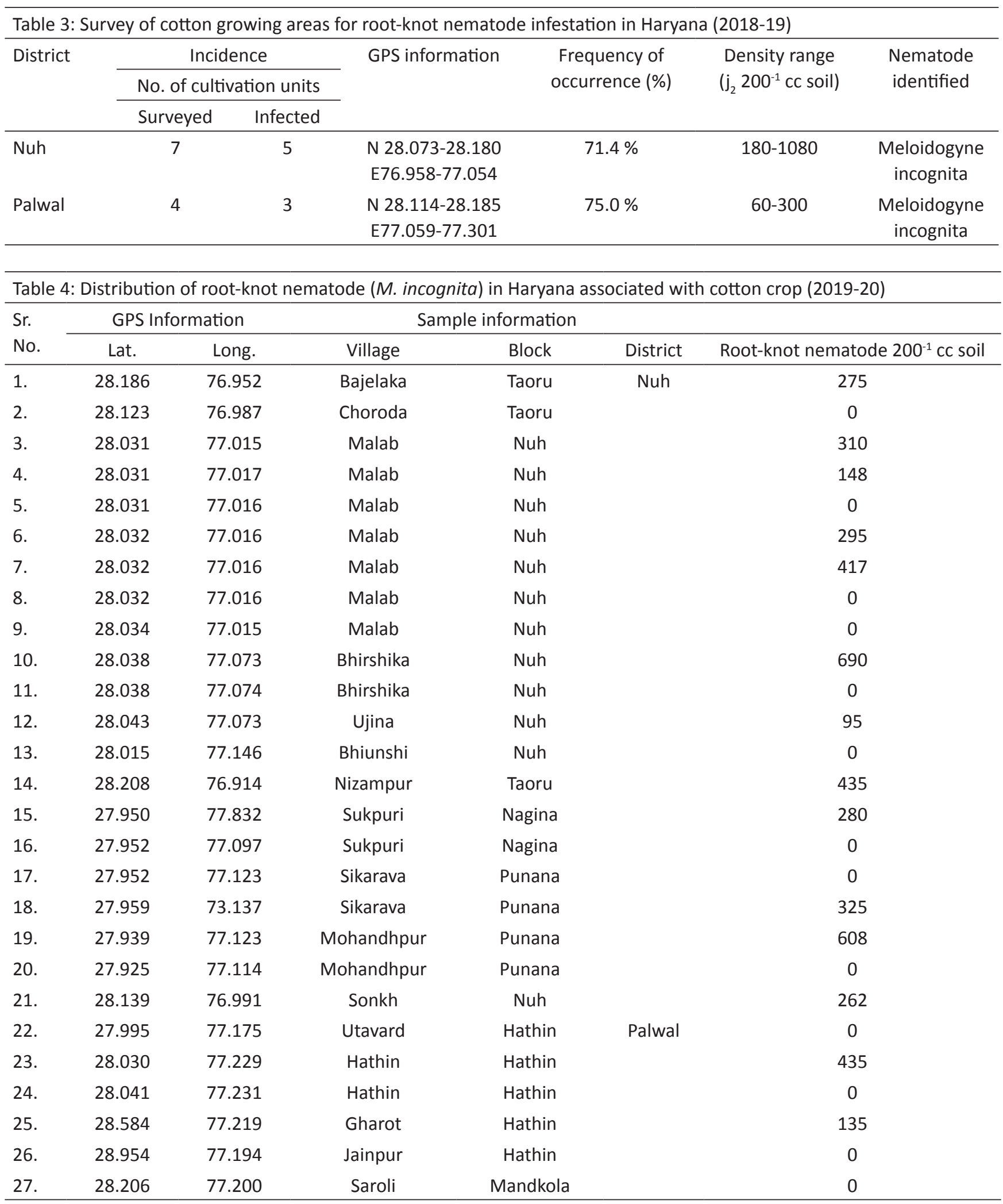

Of the nematodes recovered in this survey, only $M$. incognita and R. reniformis are currently considered to be economically damaging to cotton. The $M$. incognita was found to be the most predominant species in the soil samples of cotton rhizospheres collected from different locations. This was followed by the R. reniformis, Hoplolaimus sp., Helicotylenchus sp., Tylenchorhynchus sp. and Pratylenchus sp. The reniform nematode is prevalent in higher densities in cotton-growing 


\begin{tabular}{|c|c|c|c|c|c|c|}
\hline \multirow[t]{3}{*}{ District } & \multicolumn{2}{|c|}{ Incidence } & \multirow[t]{3}{*}{ GPS information } & \multirow{3}{*}{$\begin{array}{c}\text { Frequency of } \\
\text { occurrence (\%) }\end{array}$} & \multirow{3}{*}{$\begin{array}{l}\text { Density range } \\
\left(\mathrm{j}_{2} 200^{-1} \text { cc soil }\right)\end{array}$} & \multirow[t]{3}{*}{ Nematode identified } \\
\hline & \multicolumn{2}{|c|}{ No. of cultivation units } & & & & \\
\hline & Surveyed & Infected & & & & \\
\hline \multirow[t]{2}{*}{ Nuh } & 21 & 12 & N 27.950-28.186 & $57.14 \%$ & $95-690$ & Meloidogyne incognita \\
\hline & & & E76.952-77.832 & & & \\
\hline \multirow[t]{2}{*}{ Palwal } & 6 & 2 & N 27.995-28.954 & $33.3 \%$ & $135-435$ & Meloidogyne incognita \\
\hline & & & E77.175-77.231 & & & \\
\hline
\end{tabular}

areas of Punjab, Haryana and Uttar Pradesh (Bucker and Seshadri, 1968; Verma and Jain, 1999; Das and Gaur, 2009). A random survey undertaken in the Bt cotton-growing districts of northern Karnataka for the associated nematodes in cotton rhizosphere soil and root samples showed the presence of plant pathogenic nematodes, mainly reniform nematode (Rotylenchulus reniformis), lesion nematode (Pratylenchus sp.) and some dorylaimid pathogens (Lingaraju et al., 2012).

Of 184 samples collected from 15 'municlpios' (roughly comparable to counties) in MatoGrosso do Sul State in Brazil, $28.0 \%$ and $17.0 \%$ were positive for $M$ incognita and $R$. renformis with $45.0 \%$ and $32.0 \%$ of those samples, respectively, above the damage threshold (Asmus, 2004). In Florida, $M$. incognita was found in $61.0 \%$ of the cotton fields infested (Kinloch and Sprenkel, 1994), and in Georgia 38.0\% of the fields were infested (Baird et al., 1996). Typically, Florida and Georgia cotton-production areas are in soils that contain a high percentage of sand. $M$. incognita also has been found in 30.0\% of the cotton fields in Missouri (Wrather et al., 1992), 20.0 to $30.0 \%$ in Arkansas (Bateman et al., 2000), and $10.0 \%$ in Mississippi (Lawrence et al., 1997), respectively. This survey indicates that $M$. incognita and Rotylenchulus reniformis are widespread in the cotton production regions of Haryana (Nuh and Palwal districts). The presence and prevalence of these two economically important nematodes of cotton in this region may account for some of the widespread yield suppression that has been seen. Strategies for nematode management will be needed to improve the cotton yield in this area.

\section{Conclusion}

The association of plant parasitic nematodes especially the most important nematodes species like Meladogyne incognita, Rotylenchus reniformis, Helicotylenchus sp., Hoplolaimus sp., Tylenchorhychus and Paratylenchus sp. can cause severe economic yield loss to cotton crop in Nuh and Palwal districts of Haryana, if proper strategies are not adopted for their management. In order to overcome this problem, integrated nematode management schedule has to be adopted to reduce the yield losses in cotton.

\section{References}

Asmus, G.L., 2004. Ocorrdncia de nemátoidesfito parasitosema godoeiro no estado de MatoGrosso do Sul. NematologiaBrasileira 28, 77-86.

Baird, R.E., Davis, R.F., Alt, P.J., Mullinix, B.G., Padgett, G.B., 1996. Frequency and geographical distribution of plantparasitic nematodes on cotton in Georgia. Supplement to the Journal of Nematology 28, 661-667.

Bateman, R.J., Kirkpatrick, T.L., Robbins, R.T., Lorenz, G., 2000. The distribution of root-knot and vermiform nematodes in Arkansas, 1990-1999. In Duggar, P., Richter, D.A. (eds). Proceedings of the Beltwide cotton conferences, San Antonio, 171.

Blasingame, D., Patel, M.V., 2013. Cotton disease loss estimate committee report. In proceedings of the beltwide cotton conferences, San Antonio, TX, 7-10 January 2013, 1242-1246.

Bucker Abu, A.H., Seshadri, A.R., 1968. Report on a survey of nematode parasites associated with cotton in Madras State. Indian Journal of Agricultural Sciences 38, 470-476.

Das, D.K., Gaur, H.S., 2009. Distribution and abundance of Rotylenchulus reniformis in cotton growing areas of North India. Indian Journal of Nematology 39, 98-103.

Elling, A.A., 2013. Major emerging problems with minor Meloidogyne species. Phytopathology 103, 1092-1102

Heald, C.M., Robinson, A.F., 1990. Survey of current distribution of Rotylenchulus reiniformis in the United States. Journal of Nematology 22, 695-699.

Kinloch, R.A., Sprenkel, R.K., 1994. Plant parasitic nematodes associated with cotton in Florida. Supplement to the Journal of Nematology 26, 749-752.

Koenning, S.R., Kirkpatrick, T.L., Starr, J.L., Wrather, J.A., Walker, N.R., Mueller, J.D., 2004. Plant parasitic nematodes attacking cotton in the United States: Old and emerging production challenges. Plant Disease 88, 100-113.

Kumar, V., Khan, M.R., Walia, R.K., 2020. Crop loss estimations due to plant-parasitic nematodes in major crops in India. National Academy Science Letters. https://doi. org/10.1007/s40009-020-00895-2.

Lawrence, G.W., McLean, K.S., 1996. Reniform nematode and cotton production in Mississippi. Proceedings of the Beltwide Cotton Conferences, Memphis, TN: National Cotton Council of America, 251-253.

Lawrence, G.W., McLean, K.S., Hankins, G., 1997. Root- 
knot and reniform nematodes associated with cotton production in Mississippi. In Duger, P., Richter, D.A. (eds). Proceedings of the Beltwide cotton production research conferences, New Orleans, LA, 6-10 Jan. 1997. Memphis, TN: National Cotton Council of America, 98-99.

Lingaraju, S., Sonavane, P., Jamadar, M.M., Harlapur, S., Bhat, I.R.S., Udikeri, S.S., 2012. Plant parasitic nematodes associated with Bt cotton. Current Science 103, 926-932.

Robinson, A.F., 2007. Reniform in U.S. cotton: When where why and some remedies. Annual Review of Phytopathology 45, 263-288.

Robinson, R.T., Shipe, E.R., Rakes, L., Jackson, L.E., Gbur, E.E., Dombek, D.G., 2001. Host suitability in soybean cultivars for the reniform nematode, 2000 tests. Supplement to Journal of Nemnatologv 33, 314-317.

Sasser, J.N., Freckman, D.W., 1987. A world perspective on nematology: the role of the society. In Veech, J.A., Dickson, D.W. (eds.), Vistas on nematologi: a commemoration of the twentv-fifth anniversary of Society of Nematologists Hyattsville, MD: Society of Nematologists, 7-14.
Schindler, A.F., 1961. A simple substitute for a Baermanann funnel. Plant Disease Reporter 45, 747-748.

Starr, J.L., Carneiro, R.G., Ruano, O., 2005. Nematodes parasites of cotton and other tropical fiber crops. In: Luc, M., Sikora, R.A., Bridge, J. (eds.), Plant parasitic nematodes in subtropical and tropical agriculture. Wallingford: CABI International, 733-750.

Taylor, A.L., Sasser, J.N., 1978. Biology, identification and control of root-knot nematodes (Meloidogyne species). Raleigh, NC: North Carolina State Unviersity Graphics.

Verma, K.K., Jain, R.K., 1999. Prevalence and distribution of phytoparasitic nematodes associated with cotton in Haryana. Indian Journal of Nematology 37, 23-26.

Wrather, J.A., Niblack, T.L., Milam, M.R., 1992. Survey of plant-parasitic nematodes in Missouri cotton fields. Supplement to the Journal of Nematology 24, 779-782. 